\title{
Eusarsiella bedoyai (Myodocopida, Sarsiellidae), a new ostracode species from a marine lava cave in the Canary Islands
}

\author{
Angel Baltanás \\ Centro de Investigaciones del Agua (CSIC), La Poveda, E-28500 Arganda del Rey, Madrid, Spain \\ Keywords: Taxonomy, Ostracoda, Sarsiellidae, Eusarsiella, anchialine cave fauna, Canary Islands
}

\begin{abstract}
A new species of the ostracode genus Eusarsiella (Myodocopida, Sarsiellidae) is described from a marine lava tube in Lanzarote (Canary Islands) and compared with other species known to occur in the same geographical area. Eusarsiella bedoyai n. sp. is the second species in that genus described from anchialine caves. Its importance in determining the origin of the stygobiont fauna is briefly discussed.
\end{abstract}

\section{Resumen}

Se describe una nueva especie de ostrácodo del género Eusarsiella (Myodocopida, Sarsiellidae) procedente de un tubo de lava en Lanzarote (Islas Canarias) y se compara con otras especies conocidas del mismo área geográfica. Eusarsiella bedoyai n. sp. es la segunda especie de dicho género descrita en cuevas marinas. Se discute su significación en el origen de la fauna subterránea.

\section{Introduction}

Eusarsiella bedoyain. sp. was collected from an anchialine cave (sensu Stock et al., 1986), formed by a marine lava tube (Tunnel of Atlantis), in Lanzarote (Canary Islands). This tunnel is part of a large tube ( $7 \mathrm{~km}$ length) formed 5000 years ago by an eruption of the nearby volcano Corona. The main passage of this tunnel (10-15 $\mathrm{m}$ diameter) opens to the air in Jameos del Agua and runs under the sea bed for $1640 \mathrm{~m}$ (J. Bedoya, pers. comm.). At $730 \mathrm{~m}$ from the entrance, sand from the sea above enters through a hole in the ceiling of the gallery to form a pile ( $15 \mathrm{~m}$ base $\times 15 \mathrm{~m}$ height)
(Garcia-Valdecasas, 1985) where Eusarsiella bedoyai has been found (Fig. 1).

\author{
Description of Eusarsiella bedoyai \\ Sarsiellidae Brady \& Norman, 1896 \\ Eusarsiella Cohen \& Kornicker, 1975
}

Eusarsiella bedoyai n. sp. (Figs. 2-7)

Material. - Deposited in the National Museum of Natural History (Madrid, Spain) (MNCN). Holotype: 1 adult $\$$ bearing one egg (dissected, valves preserved in alcohol) (MNCN 20.04/8); paratype: 1 juvenile (undissected, preserved in alcohol) (MNCN 20.04/9). Canary Islands, Lanzarote, Jameos del Agua.

Holotype collected by J.L. Fernández on 17 Aug. 1985; paratype collected by members of the speleodiving group STD (Madrid) on 6 Aug. 1984 (Spanish Scientific Expedition to the Tunnel of Atlantis). All specimens were sampled from the sediment in the pile of sand at $30 \mathrm{~m}$ depth below sea level (Fig. 1).

Description of adult female. - Carapace (Fig. 2) oval in lateral view with triangular, projecting caudal process. Ornamentation: Surface with wide Ushaped rib, both branches of which joining at posterodorsal knob-like process. Smaller knob-like processes distributed along rib. Three secondary ribs extend from the main rib to the anterior margin. Surface with abundant shallow fossae. Long bristles sparsely distributed along anterior and ventral margins and along caudal process.

Carapace size: Holotype: left valve length 1.26 $\mathrm{mm}$, height $0.98 \mathrm{~mm}$; right valve length $1.24 \mathrm{~mm}$, 


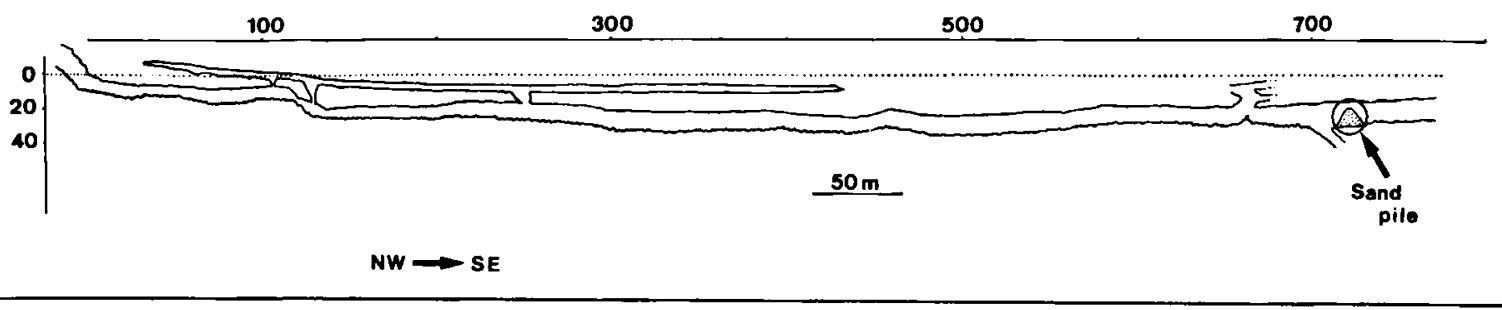

Fig. 1. Side view plan of the Tunnel of Atlantis (Jameos del Agua, Lanzarote) (after Bedoya, in Garcia-Valdecasas, 1985).

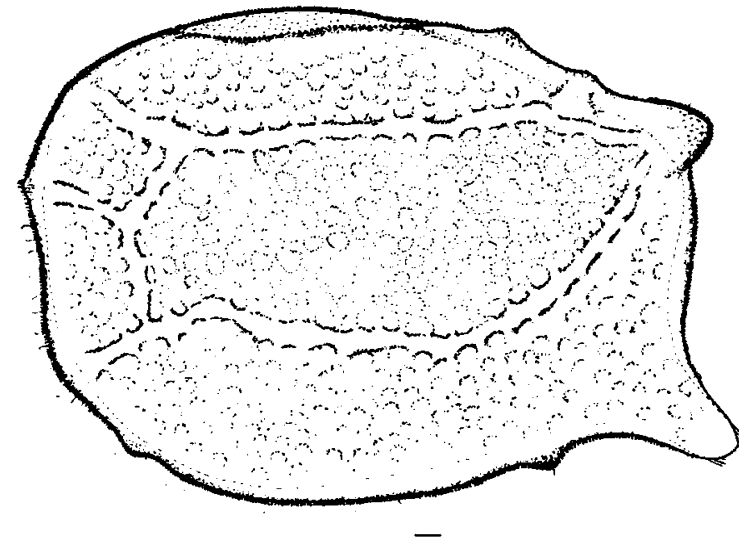

Fig. 2. Eusarsiella bedoyai $\mathrm{n}$. sp., $Q$ holotype: left valve in lateral view (scale bar $=0.05 \mathrm{~mm}$ ).

height $0.96 \mathrm{~mm}$. Paratype: left valve length 1.04 $\mathrm{mm}$, height $0.84 \mathrm{~mm}$; right valve length $0.96 \mathrm{~mm}$, height $0.82 \mathrm{~mm}$.

Antenna 1 (Fig. 3): First joint bare. Second joint with 1 spinous dorsal bristle. Third and fourth joints fused; third joint with 2 bristles (1 dorsal long and 1 ventral short, shorter than the length of the joint $3+4$; fourth joint with 3 bristles ( 1 dorsal and 2 ventral). Fifth joint: sensory bristle with 3 short marginal filaments, with blunt tip with a minute filament. Sixth joint: medial bristle short. Seventh joint: a-bristle spinous, b-bristle similar to a-bristle, both short (about one fourth of the length of the sensory bristle of fifth joint), c-bristle same length as sensory bristle with 2 minute marginal filaments. Eighth joint: d- and e-bristles bare, slightly shorter than the sensory bristle; f-bristle shorter than dand e-bristles, with 2 minute marginal filaments; gbristle of same length as the sensory bristle, with

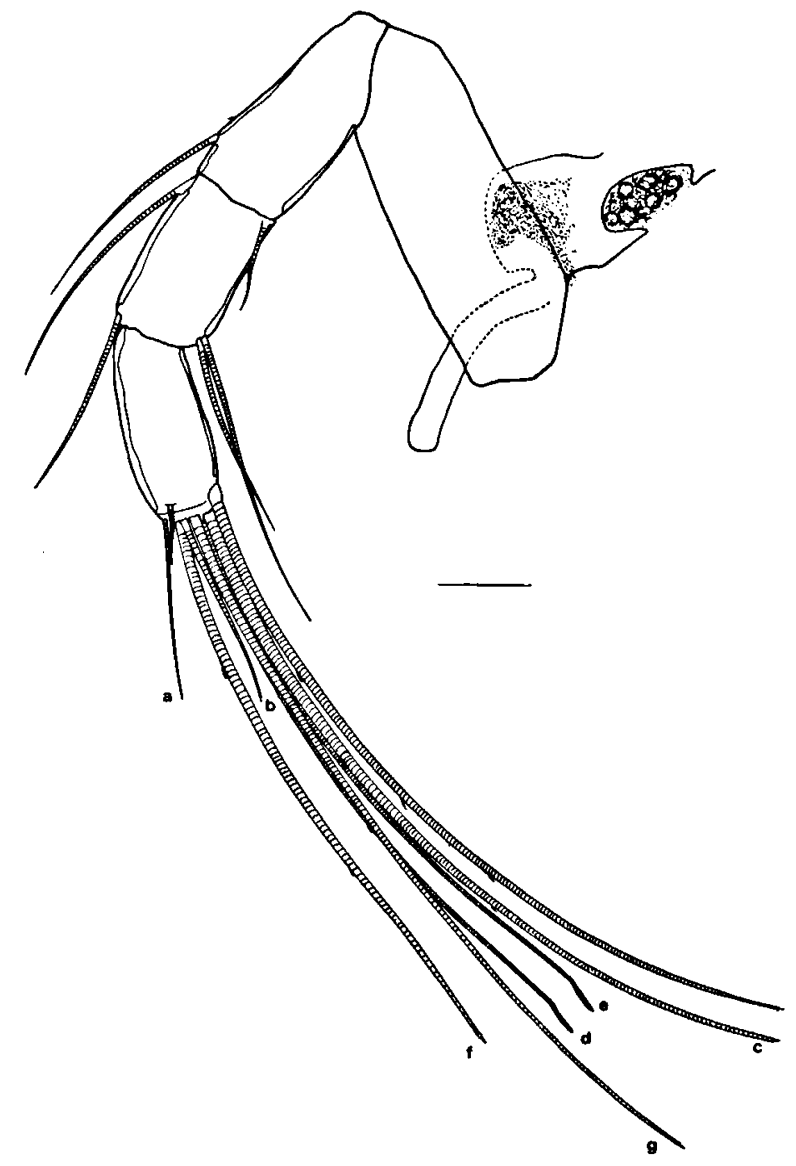

Fig. 3. Eusarsiella bedoyai n. sp., \& holotype: first antenna, Bellonci organ, and medial and lateral eyes (scale bar $=0.05$ mm).

2 minute marginal filaments; c-, f- and g-bristles with blunt tips carrying minute terminal filaments.

Antenna 2 (Fig. 4): Protopodite bare. Endopodite 1-jointed with 2 short anterior bristles and 
spinous terminal bristle with base on small protuberance. Exopodite: first joint with short recurved medial spine on terminal margin; bristle of second joint long, with natatory hairs and ventral spines; bristles of joints 3-8 with natatory hairs and spines; ninth joint with 2 bristles, 1 long with natatory hairs and ventral spines, 1 short without hairs or spines.

Mandible (Fig. 5): Coxa with short hairs on ventral margin. The coxa endite seems to be a small fold-like process near the ventral margin and near the mid-length of the coxa. Basis: 1 subterminal short spine on dorsal margin; a group of 6 bristles on or near the ventral margin: 3 proximal (one shorter than the others), 2 on the medial surface near the ventral margin, and 1 distal. Exopodite absent. Endopodite: medial surface of first joint with distal spines, ventral margin with stout bare claw; second joint with short subterminal dorsal bristle and stout ventral claw; third joint with short bristle ventral to base of terminal claw.

Maxilla: Coxa with fringe of long hairs and short dorsal bristle; 3 endites with total of 14 bristles. Endopodite: first joint with spinous alpha- and betabristles, end joint (Fig. 6a) with 2 a-bristles, 1 cbristle and 5 pectinate terminal bristles (the anterior of these ringed distally). Exopodite: 2 bristles (1 short, 1 long).

Fifth limb (Fig. 6b): Single endite with 1 short bristle. Exopodite: first joint with 2 spinous bristles; second to fifth joints fused: second joint with 3 spinous bristles; joints $3-5$ with total of 5 bristles.

Sixth limb (Fig. 6c): Single endite with 3 bristles (2 small, 1 long). End joint with 11 bristles with short marginal spines followed by 2 stout hirsute bristles.

Seventh limb (Fig. 7): All bristles cylindrical (adult character); 2 bristles in proximal group, one on each side; 5 bristles in terminal group ( 2 on one side, 3 on the other); each bristle with up to 8 bells. End teeth: two opposing rows of about three teeth each.

Furca: Each lamella (Fig. 6d) with 5 claws: claw 1 fused to lamella, remaining claws separated from lamella by suture; claws 1 and 2 with both large and small teeth along posterior margins; 2 spines on left lamella following claw 5 .

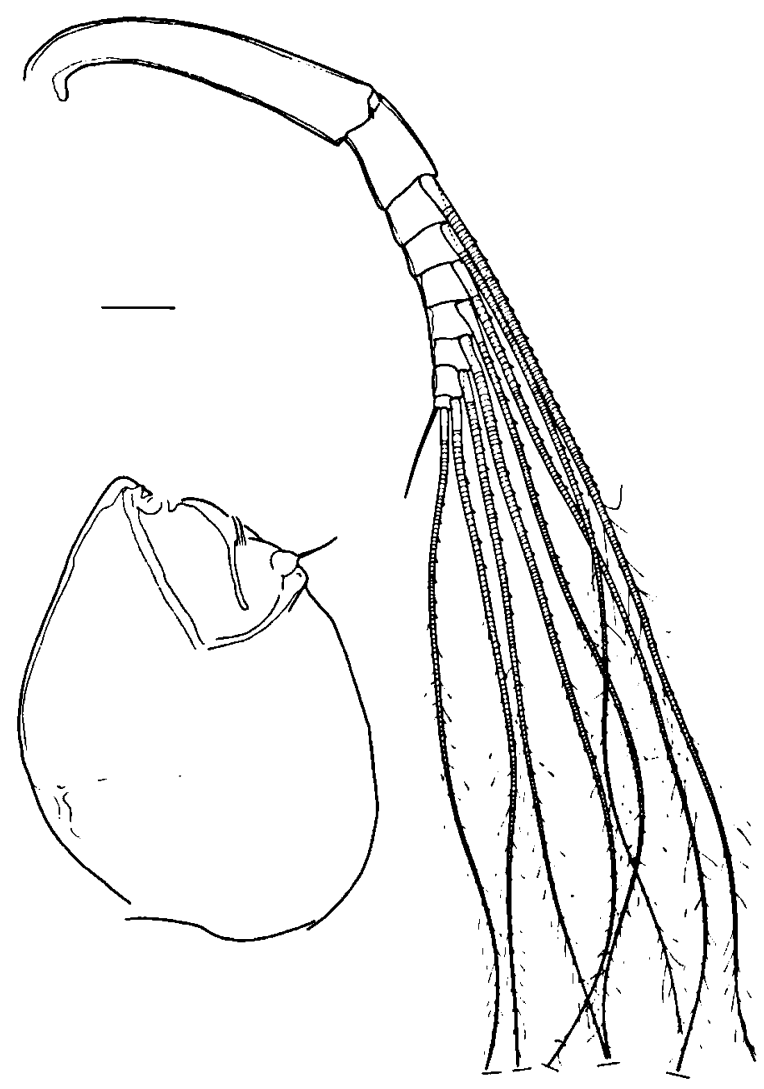

Fig. 4. Eusarsiella bedoyai n. sp., $\$$ holotype: second antenna. Protopodite/endopodite and the nine-jointed exopodite illustrated separately (scale bar $=0.05 \mathrm{~mm}$ ).

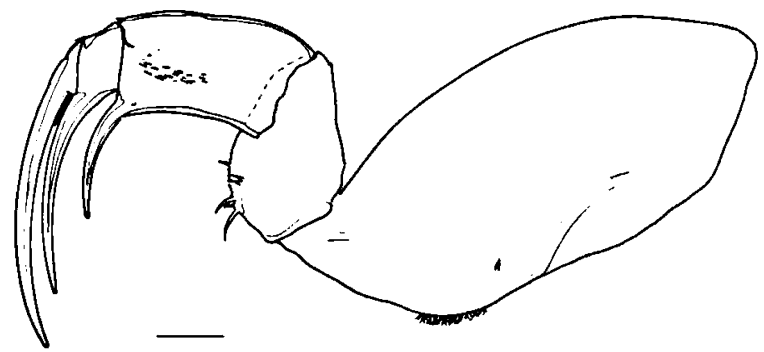

Fig. S. Eusarsiella bedoyai n. sp., \& holotype: mandible (scale bar $=0.05 \mathrm{~mm}$ ).

Bellonci organ (Fig. 3): Elongate with rounded tip.

Eyes (Fig. 3): Lateral eye smaller than medial eye. Ommatidia have not been clearly seen but about 5-8 are placed along the periphery of a matrix. 

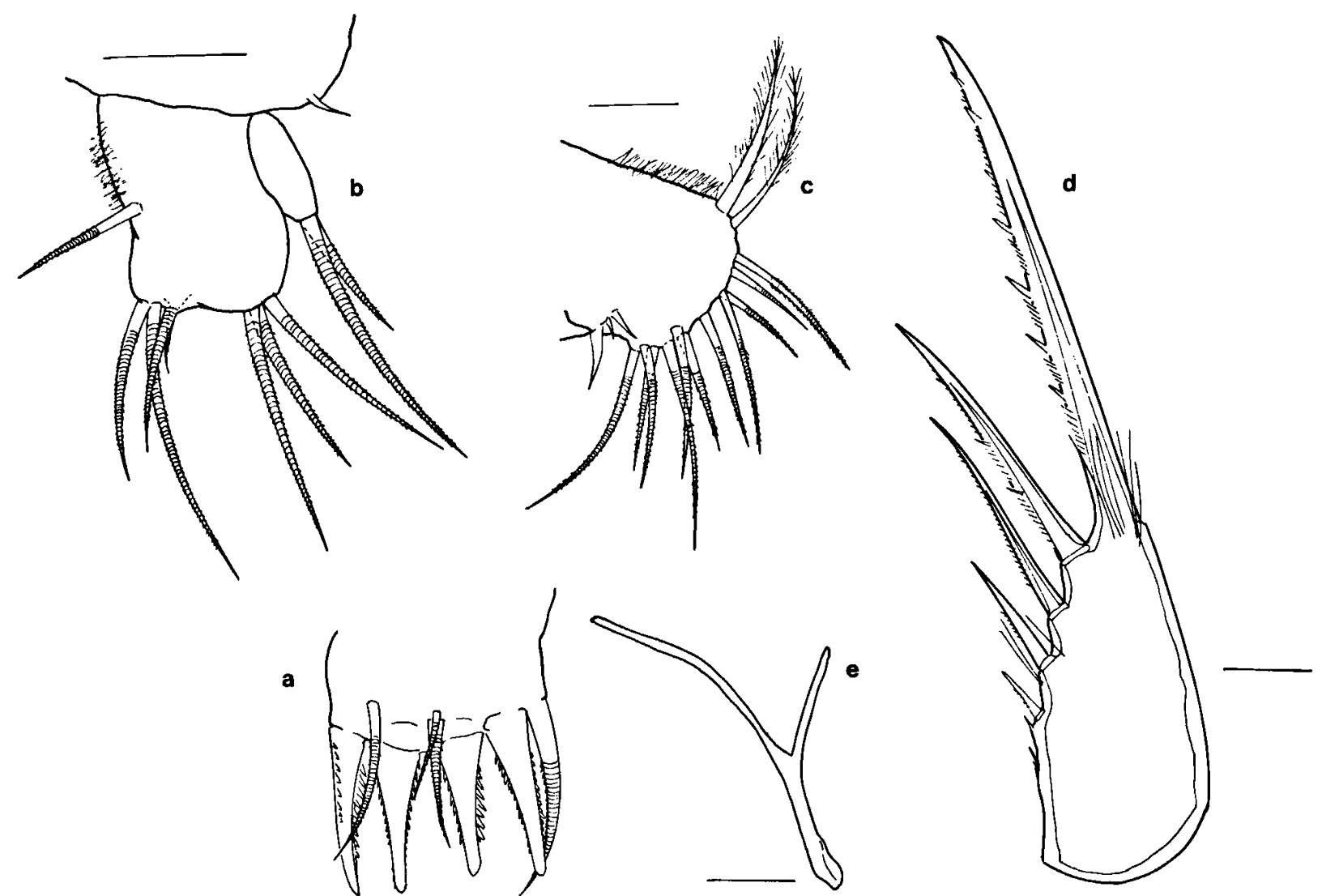

Fig. 6. Eusarsiella bedoyai n. sp., $\$$ holotype: a, maxilla, end joint of the endopodite; b, fifth limb; c, sixth limb; d, left furcal lamella; e, Y-sclerite (scale bars $=0.05 \mathrm{~mm}$ ).

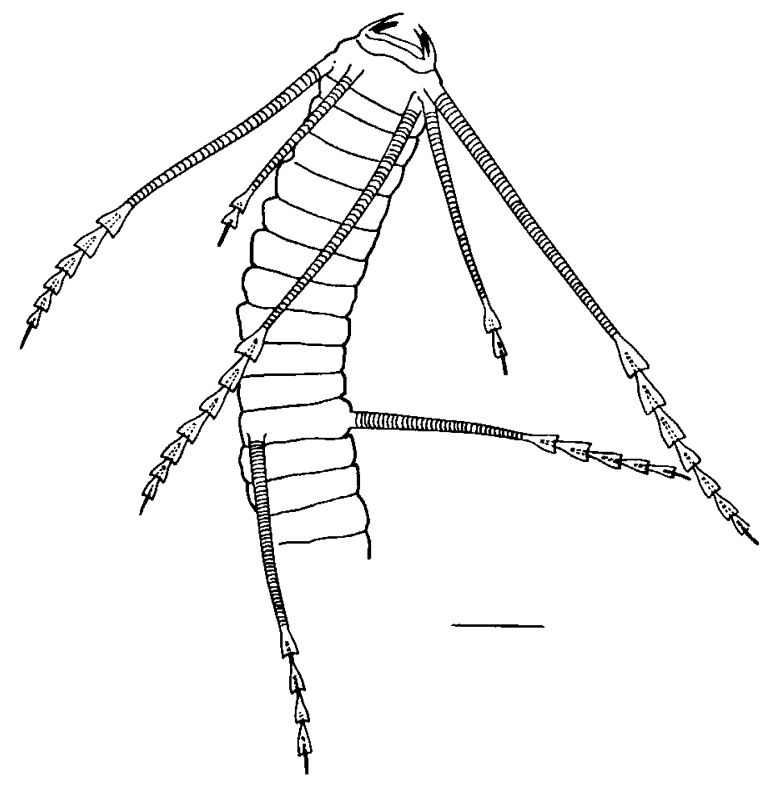

Y-sclerite (Fig. 6e): Typical for genus.

Etymology. - The species is named after José Bedoya (Museum of Natural History, Madrid), a daring speleodiver, valuable scientist and friend, who was of great help in this discovery.

\section{Discussion}

Eusarsiella bedoyai $\mathrm{n}$. sp. is assigned to the genus Eusarsiella (Ostracoda, Myodocopida, Sarsiellidae) on the basis of the diagnostic characters proposed by Kornicker (1986). It differs from similar West Afri-

Fig. 7. Eusarsiella bedoyai n. sp., $\$$ holotype: seventh limb (scale bar $=0.05 \mathrm{~mm}$ ). 
can species of Eusarsiella (see Kornicker \& Caraion, 1978) in the following unique combination of characters: large size (holotype $\mathrm{L}=1.26 \mathrm{~mm}$ ); valve with wide $U$-shaped rib and 3 secondary ribs on the anterior margin; fourth joint of first antenna with 2 ventral bristles [ 3 in $E$. capsula (Norman, 1869 ) and $E$. anommata (Kornicker \& Caraion, 1978)]; second joint of the endopodite of the second antenna with 1 bristle [bare in $E$. capsula and $E$. anommata, with 2 bristles in $E$. ocula (Kornicker \& Caraion, 1978)]; third joint of the mandible with only 1 short bristle ventral to base of terminal claw [2 in E. neapolis (Kornicker, 1974), E. africana (Kornicker \& Caraion, 1978), E. anommata, E. ocula, and $E$. rudescui (Kornicker \& Caraion, 1978)]; second joint of the fifth limb exopodite with 3 bristles ( 2 in $E$. neapolis) and third to fifth joints with 5 bristles [ 4 in $E$. capsula and E. anommata, 6 in E. ocula and E. gomoiui (Kornicker \& Caraion, 1978)]; sixth limb end joint with 11 bristles (9 in $E$. capsula, 12 in E. anommata, E. gomoiui, and $E$. rudescui, 13 in E. ocula, and 14 in E. africana); and terminal group of seventh limb with 5 bristles (6 in all other species in the area).

More than 50 species are included in the genus Eusarsiella. Most of them mainly inhabit shallow waters on the continental shelf, though some species are also known from bathyal depths (e.g., Eusarsiella africana, E. rudescui). Apart from Eusarsiella bedoyai $\mathrm{n}$. sp. only one species has been recorded from cave habitats, viz. Eusarsiella styx Kornicker \& Iliffe, 1989. It seems that these species are not truly stygobionts, but their presence in cave systems is far from occasional: $E$. sty $x$ has been collected in six different Bermudan caves at ten different dates over five years (Kornicker \& Iliffe, 1989) and $E$. bedoyai $\mathrm{n}$. sp. has been found on two different dates in the same anchialine cave. This suggests that these animals live in a habitat linking the sea bed and the cave environment. In fact Eusarsiella bedoyai $\mathrm{n}$. sp. lives in a sand mount in a lava tube, a habitat similar to the sandy substrates in which most other Eusarsiella species live.

The origin of the anchialine cave fauna is still an open question (see Iliffe et al., 1983; Iliffe et al.,
1984; Stock, 1986; Danielopol, 1990, for a controversy). Further studies on species living in the transition zone between cave and non-cave environments, like Eusarsiella bedoyai n. sp., may provide some hints on the evolutionary processes involved in the origin of the stygobiont fauna.

\section{Acknowledgements}

I thank Dr. L.S. Kornicker (Washington) for his helpful advice, and two anonymous referees for comments and suggestions. Dr. A. García-Valdecasas (Madrid) provided the paratype specimen collected during the Spanish Expedition to the Tunnel of Atlantis (1984). Financial support was received from CICYT project No. PB87/0318.

My special thanks are due to Dr. D.L. Danielopol (Mondsee) for his encouragement and help.

\section{References}

Danielopol, D.L., 1990. The origin of the anchialine cave fauna - the "deep sea" versus the "shallow water" hypothesis tested against the empirical evidence of the Thaumatocyprididae (Ostracoda). Bijdr. Dierk., 60: 137-143.

García-Valdecasas, A., 1985. Estudio faunístico de la cueva submarina "Túnel de la Atlantida", Jameos del Agua, Lanzarote. Naturalia Hispanica, 27: 1-56.

Iliffe, T.M., C.W. Hart \& R.B. Manning, 1983. Biogeography and the caves of Bermuda. Nature, 302: 141-142.

Iliffe, T.M., H. Wilkens, J. Parzefall \& D. Williams, 1984. Marine lava cave fauna: composition, biogeography and origins. Science, 225: 309-311.

Kornicker, L.S., 1986. Sarsiellidae of the western Atlantic and northern Gulf of Mexico, and revision of the Sarsiellinae (Ostracoda: Myodocopina). Smitson. Contr. Zool., 415: i-iv, 1-217.

Kornicker, L.S. \& F.E. Caraion, 1978. West African myodocopid Ostracoda (Sarsiellidae, Rutidermatidae). Smithson. Contr. Zool., 250: i-iii, 1-110.

Kornicker, L.S. \& T.M. Iliffe, 1989. Ostracoda (Myodocopina, Cladocopina, Halocypridina) mainly from anchialine caves in Bermuda. Smithson. Contr. Zool., 475: 1-88.

Stock, J.H., 1986. Deep sea origin of cave faunas, an unlikely supposition. Stygologia, 2: 105-111.

Stock, J.H., T.M. Iliffe \& D. Williams, 1986. The concept of "anchialine"' reconsidered. Stygologia, 2: 90-92.

Received: 25 July 1991 